\title{
Exploration on Cultivation of Innovative Talents in Architecture
}

\author{
Hai-yang REN, Fang ZHOU and Huo-rong HUANG
}

Nanyang Institute of Technology, Nanyang City, Henan Province, China

\author{
Keywords: Innovative talents, Architecture, Practice.
}

\begin{abstract}
Innovative talents in architecture in colleges and universities have become inevitable trends and requirements to promote the progress of construction industry. However, there are still a series of problems in innovative talents cultivation, such as lack of innovative awareness, aging of curriculum system, inadequate practice, single mode, and imperfect evaluation mechanism. to promote the solution of these problems, architectural education in colleges and universities should improve its cultivation of Innovative talents in the following aspects: cultivation of innovative thinking, change in training mode, reform of teaching mode, strengthening of practical training, establishment of multiple evaluation and so on, in order to improve the training quality of innovative talents.
\end{abstract}

\section{Introduction}

The process of urbanization and the rapid development of the construction industry have brought many opportunities for the architecture professionals in colleges and universities as well as unprecedented challenges. Innovation has become the most fundamental driving force for social development. Innovative professionals in architecture have become the inevitable trends and requirements for promoting industrial progress. Faced with the requirements of social development, architecture education workers should actively explore ways of innovative education, cultivate innovative talents in architectural design with a strong theoretical basis, strong practical ability, high comprehensive quality and an international perspective.

\section{The Present Situation and Existing Problems in College Architecture Education}

Architecture education has entered an unprecedented period of development in the 1990s based on the booming construction market. Under the requirements of the professional assessment standards, higher education in architecture actively standardizes training programs, reasonably determines professional training objectives, tries its best to seek new breakthroughs, creates an open and liquid academic environment and stimulates the professional vitality of architecture. Integration of Industry, Learning and Research is increasingly close. Combined with the characteristics of regional urban construction, the level and structure of local architectural education has been enriched, the professional competitiveness of architecture improved, and the restructuring and upgrading of the construction industry promoted.

However, Architecture Specialties in many colleges and universities have a short period of establishment and their professional features are not outstanding enough. Professional training modes are immature. There are some problems that cannot be neglected in the professional training mode, such as lack of innovative awareness, aging of curriculum system, insufficient practice outside school, single mode of teaching, outdated appraisal method. These problems are more and more obvious to the cultivation of innovative talents.

\section{Research on Countermeasures for Innovative Architecture Talents Cultivation in Colleges and Universities}

Innovative thinking Cultivation is the first condition for training innovative talents in architecture. The report of the 18th CPC National Congress pointed out that the scientific concept of development is the guiding principle that various work must long adhere to, and clearly proposed 
the implementation of an innovation-driven development strategy. The cultivation of innovative architecture talents in colleges and universities must adhere to the teaching concept that is people-oriented and puts innovation in the first place, follow the principles of forging ahead, being bold in reform and innovation, adapting to changes, and sustainable development, and cultivating innovative thinking must run through innovative talents cultivation. First, we must help students build a diversified knowledge structure, and promote students to build a solid theoretical foundation of architecture, practical experience and humanistic awareness. Second, we must make students thinking open and active, breaking the barriers of thinking, so that they can think in a multi-angle way, be bold to seek differences and go beyond, and pay attention to emerging technologies and make use of them. Once again, attention should be paid to the development and cultivation of students' non-intelligence factors, such as concentration, preciseness, openness of mind, strong thirst for knowledge and good volunteerism in contributing to society.

Curriculum system reform is the fundamental guarantee for training innovative talents in architecture. The architectural discipline itself is a comprehensive discipline that integrates aesthetics with science and technology. It emphasizes the combination of openness, practicability, modernity and foresight. Therefore, the architecture major in colleges and universities should build a diversified interdisciplinary architecture curriculum, based on the employment position, to guide students to a broader area of knowledge and enhance the social adaptability of architecture.

In the assignment of architectural design course, it is often reflected that students think less comprehensively. Therefore, college architecture needs to strengthen curriculum integration and optimize the overall structure of the course. (1) To link Architectural design, building structure, building physics and building materials and other courses to break the professional barriers, to focus on the convergence, infiltration and integration of professional courses, for the establishment of a balanced comprehensive professional curriculum system. (2) To strengthen the systematic training in students' architectural design performance thinking. A solid foundation of Architectural expression can improve the efficiency of the work part. (3) To Pay attention to the academic frontier and timely absorb the latest trends and advanced contents in building science and technology. The knowledge of architecture-related knowledge system is increasing rapidly, and new courses can be added according to the needs of construction enterprises. (4) To extract 3-4 weeks each academic year to form a shorter school term, which mainly arrange students for rapid design and comprehensive practice to strengthen the horizontal connection between theoretical and practical courses.

In addition to the classroom, content-rich "Second Classroom" injects new vitality into regular teaching, which enables students to think actively and broaden their horizons to meet their individualized and creative pursuits. (1) To invite architectural masters and experts to give lectures and seminars, and to create rich, varied forum salons. (2) To organize students to actively participate in various levels of challenging architectural design competitions. "Competition to promote learning" can better stimulate students' potential and creativity.

Diversification of teaching mode is an essential means to cultivate innovative talents in architecture. In the face of the ever-changing construction market, colleges and universities need to comprehensively train architecture professionals, through education in various educational, teaching methods and multi-faceted training. For junior students, the combination of theoretical teaching and practical research contributes to the formation of a correct architectural outlook and good architectural quality. Taking the theory course "Principles of Urban Planning" as an example, in addition to lecturing the theory in classroom, students can be divided into groups to carry out the course research according to their regions by which the city where the school is located is divided. In addition to field research, the use of the network, the library can also train Students' ability to collect and organize information. Students should be encouraged to collaborate, interact with each other and finally to complete a set of urban planning drawings for the entire team, then, to conduct the intergroup discussion and analysis in the form of multimedia presentations. We should create an atmosphere of active thinking, freedom and openness, and striving for innovation, and strengthen 
students' ability to apply theoretical knowledge to solve practical problems.

For senior students in architecture, "research-based" teaching can be carried out using the "design studio" teaching mode, in which teachers are employed as tutors and the tutors determine the topics that are forward-looking, pluralistic, research-oriented and innovative. Students choose appropriate topics to conduct research in groups, and mentors act as guides and consultants. "Design studio" creates a free and innovative academic atmosphere. It not only improves students' ability to Self-structure knowledge, but also exercise the students' ability to cooperate, prompting students to apply both theoretical knowledge and practice.

Practical teaching is an important way to cultivate innovative talents in architecture. "Innovation stems from practice". Architectural discipline is a discipline closely linked with practice. Most practical teaching courses in architecture major are visiting, learning-oriented, emotional-oriented and lack of opportunities to contact with actual engineering. Therefore, architecture major in colleges and universities should increase internship in the business of architects, and establish a mechanism of cooperation between schools and enterprises so that the overall quality of students and innovation ability can be strengthened in the practice of enterprises.

Corporate Architects business internships inspire the creativity in student interns. The key to creativity lies in two aspects: architectural design and construction drawing design. (1) Under the guidance of an experienced construction engineer, internship students are trained to have the ability to independently carry out architectural design and express design intent. Students are instructed not to pay too much attention to the visual communication of design results, while ignoring the essence of building as a "human" service in the final analysis. (2) The construction drawing design requires students to grasp the basic principles and methods of architectural design, strengthen students' ability to apply drawing soft wares and express in them, and possess computer graphics, data processing capabilities. but in the real design process, it is necessary to consider many factors, such as Traffic flow, fire prevention, flood control and energy saving. The overall consideration of the building is very important. Therefore, students should be guided to learn the basic normative knowledge of architectural design and enhance the integration ability of comprehensive theory.

Diversified teaching evaluation is the optimization of innovative personnel training in architecture. Objective, scientific, comprehensive and effective teaching evaluation is the direct driving force for the development of innovative ability of architecture students. Teaching evaluation should pay attention to the goal orientation, establish the quality control mechanism of the teaching process, realize the combination of the process and the result, and combine the academic achievement with the ability assessment. Evaluation objectives need to be specific, detailed and operational. For Each main course, students' usual scores can take $40 \sim 50 \%$ of the total score. The assessment contents include assignments, dissertations, research reports, design research and so on. At the end of the semester, multidimensional drawing methods are combined to form a comprehensive quality evaluation system that promotes students 'individuality development by using students' reply pictures, grouping of teachers and students, and drawing of external experts.

Colleges and universities should strengthen the management and evaluation of architects 'business internships. The internship units in which trainees are based give those corresponding scores according to uniform standards, including students' awareness of job internships, learning attitudes, problem-solving skills, creativity, practical ability, hard-working and the spirit of cooperation. Including the social assessment in one of the quality indicators of personnel training objectively reflect the effectiveness of student internships, and guide students to more proactive "on-the-job" exercise.

\section{Conclusion}

At present, high-level architectural design talents and construction management personnel who possess innovative abilities and good comprehensive qualities have become the hot spots of demand of employers. Only by avoiding the architectural design enterprises to spend manpower, material resources, and time to carry out "secondary training", can a talent training situation that has "good 
import and export" be formed in college architecture professional. Higher education architecture professionals need to constantly strive to explore, to provide more innovative architectural design talents who can Create and make a difference to promote social development.

\section{References}

[1] Brown K D, Jennings T. Social consciousness in landscape architecture education: toward a conceptual framework [J]. Landscape Journal, 2003, 22(2): 99-112.

[2] Boyer E L, Mitgang L D. Building Community: A New Future for Architecture Education and Practice. A Special Report [M]. California Princeton Fulfillment Services; 1445 Lower Ferry Road, Ewing, NJ 08618, 1996.

[3] Irving Babbittithe New Laokoon: An Essay On the Confusion of the Arts (1910). New York Come11 University Library, 20019.

[4] Yehuda E.Safran. Steven Holl: Idea and Phenomena. Switzerland: Lars Muller Publishing, 2002. 